\title{
DISCRIMINATION IN THE SMALL BUSINESS CREDIT MARKET
}

David G. Blanchflower

Phillip B. Levine

David J. Zimmerman

Working Paper 6840

http://www.nber.org/papers/w6840

\author{
NATIONAL BUREAU OF ECONOMIC RESEARCH \\ 1050 Massachusetts Avenue \\ Cambridge, MA 02138 \\ December 1998
}

We would like to thank Duane Benjamin, Karl Case, Robert Fairlie, Richard Freeman, Jon Skinner, Doug Staiger, and Steve Venti and seminar participants at the Federal Reserve Bank of Boston, CILN, and NBER Labor Studies for helpful comments and suggestions. The views expressed here are those of the author and do not reflect those of the National Bureau of Economic Research.

(C) 1998 by David G. Blanchflower, Phillip B. Levine, and David J. Zimmerman . All rights reserved. Short sections of text, not to exceed two paragraphs, may be quoted without explicit permission provided that full credit, including (C) notice, is given to the source. 
Discrimination in the Small Business Credit Market

David G. Blanchflower, Phillip B. Levine,

and David J. Zimmerman

NBER Working Paper No. 6840

December 1998

\section{ABSTRACT}

This paper uses data from the 1993 National Survey of Small Business Finances to determine the extent to which minority-owned small businesses face constraints in the credit market beyond those faced by white-owned small businesses. First, we present qualitative evidence indicating that black- and white-owned firms report similar concerns about the factors that may affect their businesses except that blacks are far more likely to report problems with credit availability. Second, we conduct an econometric analysis of loan denial probabilities by race and find that black-owned small businesses are almost three times more likely to have a loan application denied. Even after controlling for the differences in credit-worthiness and other factors that exist between black- and white-owned firms, blacks are still about twice as likely to be denied credit. A series of specification checks indicates that this gap is unlikely to be largely attributed to omitted variable bias. Third, we conduct a similar analysis regarding interest rates charged to approved loans and find black-owned firms pay higher interest rates as well. Finally, even these results are likely to understate differences in credit access because many potential black-owned firms are not in operation due to the lack of credit and those in business may be too afraid to apply. These results indicate that the racial disparity in credit availability is likely caused by discrimination.

David G. Blanchflower

Department of Economics

Dartmouth College

Hanover, NH 03755

and NBER

blanchflower@dartmouth.edu
Phillip B. Levine

Department of Economics

Wellesley College

Wellesley, MA 02181

and NBER

plevine@wellesley.edu

David J. Zimmerman

Department of Economics

Fernald House

34 Sawyer Library Drive

Williams College

Williamstown, MA 02167 


\section{Introduction}

Discrimination occurs whenever the terms of a transaction are affected by personal characteristics of the participants that are not relevant to the transaction. By far, the most commonly considered characteristics are those of race and gender. In labor markets this might translate into equally productive workers in similar jobs being paid different salaries based on their race or gender. In credit markets - the subject of study in this paper -- it might translate into loan approvals differing across racial groups with otherwise similar financial backgrounds.

In this paper we use data from the Federal Reserve Board and the U.S. Small Business Administration to examine the existence or otherwise of discrimination in the small business credit market. Discrimination in the credit market against minority-owned small businesses can have an important effect on the likelihood that that business will succeed. Moreover, discrimination in the credit market might even prevent the business from opening in the first place. We provide qualitative and quantitative evidence supporting the view that blacks are discriminated against in this market. For example, we find that black-owned firms are much more likely to report being seriously concerned with credit market problems and report being less likely to apply for credit because they fear the loan would be denied. Moreover, we find, after controlling for a large number of characteristics of the firms, that black-owned firms are substantially more likely to be denied credit than other groups. We find little or no evidence that women are discriminated against in this market.

The structure of the paper is as follows. We begin by briefly reviewing the theory of economic discrimination and provide some background to our analyses by reviewing prior research relevant to discrimination in credit markets. We then discuss the empirical framework employed in our analyses and describe the data used in the remainder of the paper. We then 
analyze the qualitative data available to us regarding the beliefs reported by small business owners. The following sections present econometric evidence of loan denial differences by race along with an analysis of possible sample selection biases. We then provide a series of caveats to these analyses. Finally, we present our conclusions.

\section{Theoretical Framework and Review of the Literature}

Most recent economic studies of discrimination draw on the analyses contained in Gary Becker's The Economics of Discrimination (1957). Becker's main contribution was to translate the notion of discrimination into financial terms. Discrimination, in this view, results from the desire of owners, workers, or customers to avoid contact with certain groups. This being the case, transactions with the undesired groups would require more favorable terms than those that occur with a desired group. Assume that the primary objective of a financial institution is to maximize their expected profits. The expected return on a loan will depend on the interest rate charged and the likelihood that a borrower defaults. The financial institution would approve any loan for which the expected return on the loan exceeded the cost of the funds to the institution. Discrimination would then result either in a) higher interest rates being charged to undesired groups having otherwise similar characteristics to the desired group, or b) requiring better characteristics (i.e. a lower expected default rate) for the undesired group at any given interest rate. In other words, the disadvantaged group might either be appraised more rigorously or, they would be given less favorable terms on the loan.

A similar connection between the likelihood of loan approval and the race of the applicant might also be found if firms employ statistical discrimination. In this case, firms use personal characteristics - such as race or gender - to infer the likelihood of default on the loan. If 
experience has suggested that certain groups of individuals -- defined by race or gender - are, on average, more or less likely to default, then the firm may use this information to economize on the costs of gathering more directly relevant information. Hence discrimination would not reflect the preferences of the owner but would rather reflect an attempt to minimize costs. Empirically, the racial characteristics of the applicant could proxy for unobserved characteristics of their credit worthiness.

There has been an active debate on the question of whether banks discriminate against minority applicants for mortgages. In particular, banks were often accused of "redlining" - that is, not granting loans for properties located in certain areas. To analyze that issue, the Home Mortgage Disclosure Act was passed which required lenders to disclose information on the geographic location of their home mortgage loans. These data, while interesting, were not sufficient to assess whether or not there was discrimination in the market for mortgage loans.

In 1992 researchers at the Federal Reserve Bank of Boston collected additional information from the lenders (Munnell et al., 1996). In particular, they tried to collect any information that might be deemed economically relevant to whether a loan would be approved. In the raw data whites had 10 percent of their loans rejected versus rejection rates of 28 percent for blacks and Hispanics. After controlling for the large number of variables collected to establish the credit worthiness of the borrowers (including, the amount of the debt, debt/income ratio, credit history, loan characteristics, etc.) blacks were still 7 percent less likely to be granted the loan. A variety of criticisms have been launched at this study (see, for example, Horne 1994; Day and Liebowitz, 1998; Harrison, 1998). Responses to these criticisms are found in Browne and Tootell (1996). 
In addition to the type of statistical analysis done in the Munnell et al. (1996) study, two other approaches have been used to measure discrimination in mortgage markets. First, Federal Reserve regulators can examine a lending institution's files to try to identify any cases where a loan rejection looks suspicious. Second, audit studies have been used with paired "identical" applicants. Such studies have also found evidence of discrimination (c.f. Cloud and Galster, 1993) although the audit approach is not without its critics (Heckman, 1998).

Another relevant literature concerns the severity of liquidity constraints affecting consumers in non-mortgage credit markets. A consumer is said to be liquidity constrained when lenders refuse to make the household a loan or offer the household less than they wished to borrow. (Ferri and Simon, 1997). A variety of studies have suggested that roughly twenty percent of U.S families are liquidity constrained. (cf. Hall and Mishkin, 1982; and Jappelli, 1990). As might be expected, constrained households are typically younger with less wealth and accumulated savings. (Hayashi, 1985; and Jappelli, 1990). Significantly, after including detailed control variables for the households financial characteristics, the research shows nonwhite households to be substantially more likely to be liquidity constrained (Jappelli, 1990; and Ferri and Simon, 1997).

We now turn to the more directly relevant evidence on liquidity constraints facing small businesses. Discrimination in the credit market against minority-owned small businesses can have a devastating effect on the success of that business. Further, discrimination in the credit market might even prevent them from opening in the first place. Evidence to that effect is provided in the significant literature on self-employment. Evans and Leighton (1989) and Evans and Jovanovic (1989) have argued formally that entrepreneurs face difficulties borrowing money. As in the discussion above, such individuals are labeled liquidity constrained by economists. Using data 
from the National Longitudinal Survey of Youth from 1966-1981 and the Current Population Surveys from 1968-1987, these authors find that, all else equal, people with greater family assets are more likely to switch to self-employment from employment. Blanchflower and Oswald (1998) studied the probability that an individual reports him or herself as self-employed. Consistent with the existence of capital-constraints on potential entrepreneurs, their econometric estimates imply that the probability of being self-employed depends positively upon whether the individual ever received an inheritance or gift. Second, when directly questioned in interview surveys, potential entrepreneurs say that raising capital is their principal problem. Holtz-Eakin et al. (1994a, 1994b), examine flows in and out of self-employment and finds that inheritances both raise entry and slow exit. Black, de Meza and Jeffreys (1996) find that housing equity plays an important role in shaping the supply of entrepreneurs. Lindh and Ohlsson (1996) suggest that the probability of being self-employed increases when people receive windfall gains in the form of lottery winnings and inheritances.

Additional evidence indicates that capital constraints for black-owned businesses are particularly large. For instance, Bates (1989) finds that racial differences in levels of financial capital do have a significant effect upon racial patterns in business failure rates. Fairlie and Meyer (1996) find that racial groups with higher levels of unearned income have higher levels of selfemployment. In an important new paper Fairlie (1998) uses data from the 1968-1989 Panel Study of Income Dynamics (PSID) to examine why African-American men are one-third as likely to be self-employed as white men. The author finds that the large discrepancy is due to a black transition rate into self-employment that is approximately one half the white rate and a black transition rate out twice the white rate. He finds that capital constraints -- measured by interest income and lump-sum cash payments -- significantly reduce the flow into self-employment from 
wage/salary work, with this effect being nearly seven times larger for black self-employed than for white self-employed in the case of black-owned firms. This paper then attempts to decompose the racial gap in the transition rate into self-employment into a part due to differences in the distributions of individual characteristics and a part due to differences in the processes generating the transitions. He finds that differences in the distributions of characteristics between blacks and whites explain only a part of the racial gap in the transition rate into self-employment. In addition, racial differences in specific variables, such as levels of assets and the likelihood of having a selfemployed father provide important contributions to the gap. He concludes, however, that "the remaining part of the gap is large and is due to racial differences in the coefficients. Unfortunately, we know much less about the causes of these differences. They may be partly caused by lending or consumer discrimination against blacks" (1998, p.14).

Finally, we know of only one paper that has investigated the specific topic of racial differentials in access to credit among small businesses. Cavalluzzo and Cavalluzzo (1998) use data from the 1988-1989 National Survey of Small Business Finances (NSSBF), conducted by the Board of Governors of the Federal Reserve System, to analyze differences in application rates, denial rates, and other outcomes by race and gender in a manner similar to the econometric models reported in this study. This paper documents that a large discrepancy does exist in credit access between whites and minority-owned firms that cannot be explained by a handful of characteristics of firms. Unfortunately, the earlier NSSBF data that they used did not over-sample minority-owned firms and focuses only on loan requests made in the preceding 12 months. This limits the size of the sample and restricts the power of the econometric tests conducted compared to the 1993 NSSBF data that we use, as described below. Moreover, those data include limited information on a firm's credit history and that of its owner, reducing the ability to identify the 
cause of the racial disparity. In fact, the authors conclude that "although our ability to draw strong conclusions from the denial analysis is limited by sample size, at this point, we have no evidence that points unambiguously to prejudicial discrimination as a cause of the black disadvantage" (p. 790). Our study provides an increased sample size of minority-owned firms, better statistical controls for credit-worthiness, an extensive set of specification checks designed to examine alternative interpretations of our results, along with qualitative evidence all designed to distinguish whether racial disparities in credit access can be attributed to discrimination.

\section{Empirical Framework and Description of the Data}

Disputes about discrimination typically originate in differences in the average outcomes for two groups. For example, suppose black-owned firms are less likely to be approved for a loan than white-owned firms. Is such a difference due to discrimination? To answer this question it is appropriate to compare black and white firms that have similar risks of default. In effect, we want to know what fraction of the black firms' loans would have been approved if they had the same credit worthiness as the white firms. A standard approach to this problem is to statistically control for characteristics of the firms that are deemed to be relevant to the loan decision. If we compare firms that have the same likelihood of default and yet find the black firms to be less likely to be approved then it would be appropriate to attribute such a difference to discrimination.

Following in the spirit of the Munnell et al. (1996) study we estimate the following loan denial equations:

$$
\operatorname{Prob}\left(D_{i}=1\right)=\beta_{0}+\beta_{1} * C W_{i}+\beta_{2} X_{i}+\beta_{3} R_{i}+\varepsilon_{i}
$$

where $D_{i}$ represents an indicator variable for loan denial for firm i, CW represents measures of credit worthiness, X represents other firm characteristics, and R represents the race of the firm's 
ownership. Within the framework of this model, evidence of discrimination would appear if $\beta_{3}$ is less than zero. It is important to recognize at this point that a finding that $\beta_{3}$ is less than zero does not identify whether the source of the discrimination is prejudice on the part of banks or statistical discrimination. We apply a more legalistic definition of discrimination here that would encompass any disparity in loan denial rates between applicants of different races that is not attributable to differences in other characteristics besides race.

To examine whether such a disparity exists, we use national data available from the 1993 National Survey of Small Business Finances (NSSBF). These data contain substantial information regarding credit availability on a nationally representative sample of small businesses. The survey was conducted during 1994-95 for the Board of Governors of the Federal Reserve System and the U.S. Small Business Administration; the data relate to the years 1992 and 1993. The data file used here contains 4,637 firms with less than 500 employees. ${ }^{1}$ In the NSSBF file minority-owned firms were over-sampled, but sampling weights are provided to generate nationally representative estimates. Of the firms surveyed, 12 percent are owned by blacks, 6 percent are owned by Hispanics, and individuals of other races (mostly Asian/Pacific Islander, but some American Indian/Eskimo and mixed race) own 7 percent.

Table 1 presents weighted sample means from these data for these four racial groups. The estimates indicate that black-owned firms are more than twice as likely to have a loan application rejected relative to white-owned firms (65.9 percent versus 26.9 percent). ${ }^{2}$ Other minority groups

1 The median size was 5.5 and mean size was 31.6 full-time equivalent employees; 440 firms out of 4,637 had 100 full-time equivalent employees or more. For further details of the NSSBF survey see Appendix A.

2 The 1987 NSSBF also conducted by the Board of Governors of the Federal Reserve System and used by Cavalluzzo and Cavalluzzo (1998) also contained information on loan applications and denial rates. Unlike the 1993 survey, minorities were not oversampled. Also the survey only inquires about loans made over the preceding twelve months compared to three years in the 1993 survey so sample sizes are smaller $(n=686)$. Denial rates 
are denied at rates higher than whites as well, but the magnitude of the black-white differential is especially striking. Minority-owned firms, however, do have characteristics that are different than those of white-owned firms that may contribute to these differences. For instance, minorityowned firms were younger, smaller (whether measured in terms of sales or employment), and more likely to be located in urban areas, a sole-proprietorship and with an owner with fewer years of experience than their white counterparts. Black-owned firms, in particular, were also generally less credit-worthy than firms owned by other racial groups measured by whether the owner had: a) been bankrupt over the preceding 7 years b) over the prior three years had been delinquent for more than 60 days on personal obligations c) had legal judgments against him or her over the previous three years and d) whether, over the preceding three years, the firm had been delinquent for more than 60 days on business obligations.

\section{Qualitative Evidence}

Before moving on to the results of our multivariate analysis, we first report on what business owners themselves say are the main problems confronting them. Table 2 reports the results of asking specific questions about problems confronted over the 12-month period before the date of interview. In the top panel respondents were asked to what extent credit market conditions had been a problem. Blacks were much more likely to say that it had been a "serious" problem (31 percent) than Hispanics (23 percent) or whites (13 percent) or those from other racial groups (13 percent). The bottom panel of the table reports the results for eight other designated problem areas -- i) training costs; ii) worker's compensation costs; iii) health insurance

(weighted) are considerably lower for minorities: white-owned firms had a denial rate for loans of $22 \%$ compared with $56 \%$ for blacks, $36 \%$ for Hispanics and $24 \%$ for other races, which are broadly similar to the differences reported here. 
costs; iv) IRS regulation or penalties; v) environmental regulations; vi) The American with Disabilities Act; vii) the Occupational Safety and Health Act; viii) The Family and Medical Leave Act. Differences by race are much less pronounced in these eight areas than they were in relation to credit market conditions. We also estimated a series of ordered logit equations (available on request from the authors) to control for differences across firms in their credit-worthiness, location, industry size, and the like. It is apparent from these regressions that blacks were more likely to report that credit market conditions were especially serious. Only in the case of the Family and Medical Leave Act were blacks significantly more likely to report this problem. The finding that black firms are largely indistinguishable from white firms in reporting a variety of problems, except for the case of credit, suggests that credit really is a problem for minority-owned firms.

Table 3A provides supporting evidence for these results with the NSSBF with data from another entirely different survey -- the 1992 Characteristics of Business Owners Survey, 1992 which was conducted by the Bureau of the Census. ${ }^{3}$ Firms were asked to report the impact of various kinds of costs upon their profitability. Blacks and Hispanic-owned firms report stronger negative impacts of credit market conditions, a lack of financial capital and crime. There are no strong differences by race or gender for the other reasons. Table 3B presents results from the same data source on the reasons why a discontinued business was unsuccessful. Multiple responses are possible. Black-owned, and to a lesser degree, Hispanic-owned firms were much more likely to report that the reason was due to the lack of access to business or personal loans or credit than was true for other races.

3 For further details of the survey see the Data Appendix at the end of this report. The full Census Bureau report is available from the following Census Bureau website -- http://www.census.gov/agfs/www/cbo.html. 
Table 4 reports the views of NSSBF respondents on the most important issue they reported they were likely to have to confront over the 12-month period from the date of interview. Credit availability again appears to be an issue for minority firms. For blacks it was the most important reason - one in five gave this response. In contrast only 6 percent of white owners and 5 percent of Hispanics gave this answer. Whites were especially worried about health care costs. In summary, black owners report that they had problems with the availability of credit in the past and expected that such difficulties would continue into the future. ${ }^{4}$

\section{Estimates of Differences in Loan Denial Rates by Race/Ethnicity}

Evidence presented to this point indicates that minority-owned firms are more likely to be denied loans and report that their lack of access to credit significantly impairs their business. Can these differences be explained by such things as differences in size, credit-worthiness, location etc. as some have suggested in relation to the parallel work on discrimination in mortgage lending (see Horne, 1994; Bauer and Cromwell, 1994, and Yezer, Phillips and Trost, 1994)? To address this question we now turn to an econometric examination of whether the loan requests made by minority-owned firms are more likely to be denied, holding constant differences across firms. As we show below, we find strong statistical evidence of discrimination in the market for small business credit.

In Table 5 the results of estimating a series of loan denial probit regressions using data from the 1993 NSSBF are reported. As indicated earlier, this survey has the particular advantage

\footnotetext{
4 We spoke with a representative of the Massachusetts Commission Against Discrimination to determine the extent to which minority-business owners pursue legal recourse in cases in which they have had small business loan applications denied. Apparently, few such cases are ever filed, but the Commission does not conduct any outreach activities to increase awareness of the law and the possibility of legal action.
} 
that it includes a number of variables that can be used to proxy an applicant's credit-worthiness. All estimates are obtained from probit models of loan denials. We report estimated derivatives from these models that can be interpreted as the effect on the probability of loan denial of an infinitesimal change in each independent continuous variable and the discrete change in the probability for dummy variables. In Column 1 which contains only race and gender indicators, for instance, the coefficient of 0.426 can be interpreted as indicating that the denial rate for blackowned businesses is 42.6 percentage points higher than that for those firms in the excluded category of white-owned firms. This estimate simply replicates the raw difference in denial rates between black- and white-owned businesses reported earlier.

The remainder of Table 5 includes additional explanatory variables to hold constant differences in the characteristics of firms that may vary by race. ${ }^{5}$ In Column 2 a number of controls are included that distinguish the credit-worthiness of the firm and the owner. Virtually all are statistically significant on a two-tailed test at conventional levels of significance with the expected signs. Having been bankrupt or had legal judgments against the firm or owner raises the probability of denial; stronger sales lowers this probability. Even after controlling for these differences in credit-worthiness, black-owned firms remain 28 percentage points more likely to have their loan request denied compared to white-owned firms. The models reported in Columns 3 and 4 control for a vast array of additional characteristics of firms, including its size and age, its organizational type, the educational qualifications of the owner, whether or not it had any

\footnotetext{
${ }^{5}$ We have also estimated these models separately, focusing specifically on the differences in coefficient estimates between whites and blacks. The F-Test we conducted to determine whether parameter estimates were the same for blacks and whites rejected this null hypothesis. Then we used the estimates obtained by estimating the model separately by race and conducted an Oaxaca (1973) decomposition. The results from this analysis were similar to those obtained by restricting the coefficients to be the same between blacks and whites and using the coefficient on a black indicator variable to measure the gap between groups. We have chosen to report all the results in this simpler format for ease of exposition and interpretation.
} 
business lines of credit or revolving credit agreements in 1993, and its location and industry. The estimated disadvantage that black-owned firms face in obtaining credit is virtually unchanged even after including this extensive list of control variables. These firms are still about 25 percentage points more likely to have their applications denied compared with white-owned firms. We also experimented with a number of other controls including profitability, equity (assets less liabilities), values of inventory, wages and salaries paid to workers and officers' cash holdings, the value of any land owned by the firm and the type of financial institution used but they never achieved significance and were omitted. ${ }^{6}$ The results also indicate that Asians/Pacific Islanders also had significantly higher denial rates than whites. There is no evidence that denial rates for firms owned by women or other racial groups were significantly different from the denial rates of firms owned by whites.

An important consideration in interpreting the results reported so far is whether or not we have adequately controlled for differences in credit-worthiness of firms. ${ }^{7}$ If black-owned firms are less creditworthy and we have failed to adequately capture those differences, even with our extensive set of control variables, then we would be inappropriately attributing the racial

\footnotetext{
6 Approximately four out of five (80.5\%) of the firms who required a loan applied to a commercial bank. Overall seventeen different types of financial institution were used, although only the following accounted for more than $1 \%$ of the total (weighted) -- Credit Unions (2.0\%); Savings Banks (2.5\%); Savings \& Loans (2.3\%); Finance Companies(4.9\%); Lease Companies (2.1\%) and other business firms (1.7\%).

${ }^{7}$ Another potential problem involves the type of loans for which black- and white-owned firms are applying. Black firms are more apt to apply for working capital rather than for capital expansion, equipment purchases or other reasons. These latter types of loan requests are more secure since they provide at least some of their own collateral. If blacks are less likely to apply for funds for these purposes their overall loan denial rate would be higher for reasons unrelated to discrimination. Yet we found that blacks remain at a similar disadvantage regardless of the type of credit for which they are applying. We find that blacks are 29 percent and 18 percent more likely to have their loans denied for working capital and other types of loans, respectively. These estimates are both significantly different from zero, but not significantly different from each other.
} 
difference in loan denial rates to discrimination. The next several specifications are designed to determine the sensitivity of our results to this concern.

The first problem we address pertains to the specific functional form with which we control for differences in credit history across firms. As shown in Table 1, black-owned firms are considerably more likely to have had troubles in the past in the form of judgments against them, late payments by the firm or its owner, or past bankruptcies. The model specifications reported in Table 5 implicitly assumes that these past problems are additive in their effect on loan denials and one might suspect the marginal impact would rise as past problems rise. Therefore, in the first three rows of Table 6 we separate firms by the number of types of past problems experienced. In Row 1, we restrict the sample to those firms that have never had any past credit problems. The second row restricts the sample to firms that reported only one of these problems and the third row includes firms that have experienced more than one of them. The results suggest that even black-owned firms with clean credit histories are at a significant disadvantage in getting their loans approved, holding constant their other characteristics. In fact, the estimated differential in loan approval rates between black- and white-owned firms is virtually identical in all three groups.

Next, we considered whether black-owned firms are treated differently from white-owned firms when requesting credit from other sources, including suppliers and credit card companies. If minority-owned firms really are less credit-worthy, then other types of creditors also may be reluctant to provide them with credit. On the other hand, if they approve credit requests at roughly the same rate regardless of the owner's race, then perhaps the disadvantage that blackowned firms face when they apply for loans from financial institutions is more likely attributable to discrimination. Suppliers, in particular, are likely to have had a long-standing relationship with the firm and its owner(s) and are better able to make judgments regarding credit-worthiness based 
on this knowledge. Therefore, their credit decisions are far less likely to be driven by group characteristics than may be true for financial institutions with less information that may be practicing statistical discrimination. An examination of credit cards provides a different advantage. Because credit card applications are more likely to be filled out and mailed in, it is quite likely that the race of the applicant is unknown to the financial institution. ${ }^{8}$

To address this we use data from the NSSBF, which also asked respondents whether they had been denied trade credit from a supplier and whether they use business or personal credit cards to finance business expenses. Regarding trade credit, one shortcoming of this analysis is that firms who are denied trade credit can be distinguished from all other firms, but we do not know which firms sought such credit. ${ }^{9}$ If black-owned firms were less likely to apply for such credit, the share of them that were denied would be downward biased relative to white-owned firms. ${ }^{10}$ Subject to this limitation the results still provide useful information. Overall 6.2 percent of applicants responded that they were denied trade credit. Once more there are considerable differences by racial groups: 5.7 percent of whites answered positively compared with 13.5 percent of blacks, 6.4 percent for other races and 10.2 percent of Hispanics.

In Row 4 of Table 6 we modeled the probability of a request for a trade credit application being denied on the full sample of 4,480 observations (only firms with missing values are deleted)

\footnotetext{
${ }^{8}$ In fact, it is our understanding that it is illegal for creditors to ask an applicant about his/her race on a credit application. Lenders to small businesses appear to be exempt from this restriction, from what we can determine, so long as they are asking whether the entity is a certified minority-owned small business for the purpose of determining eligibility for Small Business Administration loan guarantees. In either case, it is illegal to use race as a factor in determining whether or not to grant a loan.

9 The exact wording of the question was "has any supplier that offers trade credit to business customers denied a request by your firm for trade credit -- yes or no?"

10 Interestingly the current use of trade credit varied only a little by race. Respondents were asked if the firm purchased any goods or services on account during 1993 rather than pay for them before or at the time of delivery: $64.8 \%$ of white-owned firms answered in the affirmative compared with $60.7 \%$ for blacks; $55.1 \%$ for Hispanics
} 
controlling for measures of credit-worthiness and other firm characteristics. Results of this analysis suggest that black-owned firms are only 3 percent more likely to be denied trade credit compared to white-owned firms, ceteris paribus, which is very small compared to the 25 percent difference observed in financial loan applications. This finding can be interpreted in one of two ways. Firms' trading partners may also discriminate against minority-owned firms, but to a far lesser extent. Alternatively, if trade credit is granted without any discrimination, then this 3 percent estimate indicates the extent to which our measures of credit-worthiness fail to capture differences between white and minority-owned firms. Either way, the gap between this estimate and that obtained regarding the loan decisions of financial institutions' strengthens our conclusion that these institutions treat minority-owned firms unfairly.

In Rows 5 and 6 of Table 6 we examine the probability that a firm uses either a business credit card (Row 5) or a personal credit card (Row 6) to finance business expenses in $1993 .{ }^{11}$ In neither case could we find any evidence that black-owned firms were less likely to have access to such cards. We also had information available on the maximum amount that could be billed to these accounts and could find no significant differences by race in a regression that modeled the amount that could be charged. No racial differences were observed when we modeled the typical balance remaining on these cards at the end of a typical month.

The final approach we undertook to determine whether our model adequately controls for differences in credit worthiness was to compare our measures to the information requested when a small business applies for a loan. To do this, we went to some local banks and obtained small

and $55.7 \%$ for other races.

${ }^{11}$ On average, 29 percent of all firms use business credit cards and 41 percent use personal credit cards for business use; these levels vary only modestly by race/ethnicity. Blanchflower, Evans and Oswald (1998a) use these same data to examine the role of credit cards and find that the presence of business credit cards enhances employment growth. Blanchflower, Evans and Oswald (1998b) used data from various Surveys of Consumer 
business loan applications. To supplement this small sample, we searched the internet and examined web sites that provide general business advice to small firms, including a description of the loan application process and the information typically requested of applicants. An example of a typical application form is presented as Appendix B. We found that detailed information is requested of both the firm and its owner. Regarding the firm, banks typically request information like the following: (a) type of business, (b) years in business, (c) number of full-time employees, (d) annual sales, (e) organization type (corporation or proprietorship), (f) owner's share, (g) assets and liabilities, (h) whether the business is a party to any lawsuit, and (i) whether any back taxes are owed. Regarding the owner's personal finances, banks typically ask for: (a) assets and liabilities, (b) sources and levels of income, and (c) whether the owner has any contingent liabilities. Some applications ask explicitly if the firm qualifies as a minority-owned enterprise for the purposes of certain government loan guarantee programs. The race of the applicant, however, would be readily identifiable even in the absence of such a question since most of these loans would be originated through face-to-face contact with a representative of the financial institution.

These criteria seem to match reasonably closely the information available to us in the NSSBF. The particular strength of the survey is the detail available on the firm, which covers much of the information typically requested on loan application forms. Less detail is available for the owner of the firm. On the other hand, we have no direct information regarding the owner's assets, liabilities, and income, which would be necessary to determine the personal collateral available should the firm default on its obligation. However, we do have information regarding the characteristics of the owner that are frequently used as correlates of these factors, like their education and experience. In addition, we have data on the owner's financial history, including 
whether or not they have been delinquent on previous loan payments or have gone bankrupt in the past seven years. Nevertheless, our potentially incomplete characterization of the business owner's financial condition may introduce a bias into our analysis if black business owners have fewer personal resources than white business owners to cover the loan should the firm default.

We conducted several additional analyses to assess the potential impact of this problem on our results by separately examining groups of firms who differ in the degree to which personal finances should influence the loan decision. For instance, in Table 6, Rows 7 and 8 we consider proprietorships/partnerships separately from corporations and estimate the disadvantage experienced by black-owned firms in obtaining credit. Since owners of an incorporated business are significantly shielded from incurring the costs of a failed business, differences in personal finances should be far less important in evaluating the loan applications they file. But our estimates indicate that black-owned firms are still almost 25 percent less likely to have their loan application approved regardless of whether the business is organized as a corporation or proprietorship/partnership.

We also considered differences in loan approval rates by race for larger firms versus smaller and for older firms versus younger. ${ }^{12}$ In both cases one might expect the owner's personal finances would be less important. Our results, reported in Rows 9 through 12 of Table 6 indicate that black-owned firms face similarly lower rates of loan denials regardless of their size or age.

One additional factor that suppliers of credit may consider in determining loan approvals is the specific location of the firm. If a firm is located in the center city, for example, banks may

\footnotetext{
${ }^{12}$ The mean and median age of firms in the survey is 15 and 12 years, respectively. Only 14.5 percent are less than five years old and only 4.1 percent are less than three years old. As reported in footnote 1, the mean and median size of firms is 5.5 and 31.6 full-time equivalent workers, respectively. Fourteen percent of firms have one or fewer employees and 27 percent have two or fewer employees.
} 
judge the future profit prospects of these firms as more uncertain and may be less likely to approve the loan. Although such behavior may be consistent with profit maximization, if blackowned firms were more likely to be located in these areas it would still qualify as statistical discrimination and would be illegal.

Although we do not know the specific location of the firms in the NSSBF data, we conducted two additional specification checks to see if lenders' behavior was consistent with this hypothesis. First, we separated firms by whether the were located in an SMSA, since those not in an SMSA cannot be located in the central city. Second, we separated firms by their industry classification into those in retail trade, repair services, and personal services and firms in all other industries. We chose these categories in order to distinguish those firms whose market is more likely to be local (like a neighborhood grocer, hair stylist, or auto mechanic) compared to those who sell their products/services to the broader community. ${ }^{13}$ If locating in the central city has any impact on future profit expectations, it should be greater for those firms whose market is more local in nature. Therefore, if minority-owned firms are more likely to locate in these areas, racial differences in loan approval rates should be smaller in the other industries.

The results of these tests, reported in Rows 13 through 16 of Table 6, reject the hypothesis that differences in loan denial rates are attributable to different propensities to locate in the center of a city. We find no difference in loan denial rates between white- and black-owned firms in the retail trade, personal services, and repair services industries, but a substantial difference in other industries. This pattern is the opposite of what we would have predicted if lenders discriminated against central city locations, assuming black-owned businesses are more

\footnotetext{
${ }^{13}$ We examined the sensitivity of the results to this definition by looking at retail trade only, then including just repair services, including construction businesses, etc. and found the results to be robust to these alternatives.
} 
likely to locate there. In addition, although we do find that black-owned firms located in an SMSA face a larger disadvantage in obtaining credit, those in other locations still experience about a 25 percent greater likelihood of having a loan application denied.

Although most of our analysis has addressed whether minority and white-owned firms are treated equally in terms of their probability of loan denial, another way that differential treatment may emerge is through the interest rate charged for approved loans. Discrimination may be apparent if banks approve loans to equally credit-worthy minority and white-owned firms, but charge the minority-owned firms a higher rate of interest. ${ }^{14}$ Therefore, we estimated model specifications analogous to those reported previously for loan denials, but now the dependent variable represents the interest rate charged for firms whose loans were approved. In these models, we also control for whether the loan carried a fixed or variable interest rate since fixed rate loans charge a premium to cover their additional risk.

The results of this analysis for all approved loans, reported in Row 1 of Table 7, indicate that black-owned firms pay rates of interest that are approximately one percentage point higher than white-owned firms after controlling for differences in credit-worthiness. Even black-owned firms with good credit histories are charged higher interest rates (Row 2). ${ }^{15}$ The remainder of the Table presents similar specification checks to those reported in Table 6. Recall that most of these models identify firms for which the firm's own history is likely to be a more important contributor to its creditworthiness. The specifications by SMSA and industry are designed to distinguish those firms located in center cities or whose products/services are more likely to be sold in the

14 The size of the loans requested by, or granted to, white and minority-owned firms are not statistically significantly different.

${ }^{15}$ We do not report results for firms that have had past credit problems because their higher likelihood of being denied credit significantly restricts our ability to provide a powerful test of the interest rates they are charged if 
local marketplace. Although sample sizes are smaller for approved loans and reduce the power of this analysis, we find little evidence that interest rate differentials charged to black-owned firms differ between proprietorships/partnerships and corporations, older and younger firms, bigger and smaller firms, and industry. The limited power of the analysis makes it difficult to draw conclusions regarding differences by a firm's location in an SMSA. Overall the evidence presented indicates that blacks face a significant disadvantage in the market for small business credit that does not appear to be due to differences in credit-worthiness or even their geography.

\section{Loan Approval Rates versus Access to Credit}

In fact, these results may be biased toward finding too small a disparity between white and black-owned firms because those minority-owned firms that actually apply for credit may represent a selected sample of the most credit-worthy. More marginal minority-owned firms whose loans may have been accepted had they been owned by whites may not even be among the pool of loan applicants. First, these firms may have gone out of business or may not have had the opportunity to commence operations because of their inability to obtain capital. Second, some existing firms may have chosen not to apply for credit because they were afraid their application would be rejected due to prejudice.

approved. 
Although we have no evidence supporting the first proposition, data from the NSSBF provides some support for the second: black- and Hispanic-owned firms are much more likely to report that they did not apply for a loan, even though they needed credit, because they thought they would be rejected. Table 8 reports estimates from Probit models in which the dependent variable is an indicator variable representing failure to apply for a loan fearing denial for all firms. The first row presents racial differences without controlling for any other characteristics of firms and the results indicate that black- and Hispanic-owned firms are 40 and 22 percentage points more likely to withhold an application fearing denial than are white-owned firms. ${ }^{16}$

Of course, some of this difference may be attributable to differences in credit-worthiness across firms since firms that are bad credit risks should be afraid that their loan would be denied. To adjust for this, the second row of Table 8 reports comparable models that control for differences in credit-worthiness and other characteristics of firms. The results from this specification does show that the higher degree of fear of rejection among black-and Hispanicowned firms can partially be explained by these differences. Nevertheless, a gap of 26 and 15 percentage points still exists between black-and Hispanic-owned firms, respectively compared to white-owned firms. In fact, when asked directly why they were afraid to apply for loans, minority-owned firms were far more likely to report prejudice as the reason (18 percent for blackowned firms, five percent for Hispanic-owned firms, and two percent for white-owned firms). ${ }^{17}$

If these minority-owned firms had applied for credit and were rejected because of discrimination, estimates of racial disparities only based upon loan applicants would be

\footnotetext{
${ }^{16}$ The actual percentages for each group are: 22.5 percent for white-owned businesses, 41.7 percent for firms owned by Hispanics, and 60.8 percent for black-owned businesses.

17 The other reasons given, including too little collateral, poor credit history, and poor balance sheet, are comparable across groups (firms could report more than one reason).
} 
understated. The perception of prejudice, however, among these firms does not necessarily imply that selection bias is present. Those firms that failed to apply because they feared rejection may have had similar loan denial rates as other minority-owned firms with comparable levels of creditworthiness that did apply. If those firms chose to apply for a loan, differences by race in the combined denial rate of the actual and potential applicants would be the same as we have estimated for the observed sample of applicants.

More formally, suppose that loan denial rates for equally credit-worthy white- and minority-owned firms that applied for credit are $\theta^{\mathrm{W}}$ and $\theta^{\mathrm{m}}$, respectively; the measure of discrimination employed in the previous analysis is $\theta^{\mathrm{m}}-\theta^{\mathrm{W}}$. Now suppose that firms that are equally credit-worthy, but chose not to apply for a loan because they feared rejection, would have been denied at the rates $\theta^{\mathrm{W}}$ and $\psi^{\mathrm{m}}$ for white- and minority-owned firms, respectively. Among the white-owned firms, the denial rate is identical regardless of whether the firm chose to apply or not, conditional upon credit-worthiness. Among minority-owned firms, however, those who were afraid to apply may have been denied at a higher rate (perhaps because of their greater propensity to locate in the central city or other factors that are related to their race, but unrelated to creditworthiness) compared to other minority-owned firms. Then the correct representation of the disadvantage faced by minority-owned firms is $\left[\eta \theta^{\mathrm{m}}+(1-\eta) \psi^{\mathrm{m}}\right]-\theta^{\mathrm{w}}$, where $\eta$ represents the share of minority-owned firms desiring credit that submitted an application. Our earlier findings are biased if $\theta^{\mathrm{m}}$ is not equal to $\psi^{\mathrm{m}}$.

One approach that is frequently employed to address such a problem is to estimate a "Heckman-correction" that would formally model the application process in conjunction with the loan outcome for those who applied. The difficulty with this methodology in the present context 
is that it is only correctly implemented when some variable is present that is correlated with a firm's decision to apply for a loan, but is independent of the financial institution's decision to approve or deny the request. Unfortunately, the NSSBF data does not appear to contain any variables that would satisfy these conditions, so we are unable to implement this methodology. ${ }^{18}$

As an alternative that answers a different, but related question, we consider the ability of firms to get credit among those who desired it, regardless of whether or not they applied. This amounts to analyzing access to credit rather than loan approval and includes in the denominator those firms that needed credit but did not apply because they feared rejection. If differences by race in this rate among all firms who needed credit are greater than differences by race in the rate of denial among loan applicants, then this would indicate that black- and Hispanic-owned firms have even less access to credit than an analysis of loan applicants would indicate.

To test this proposition, we estimate a regression model comparable to the one reported in Table 5 for the sample of firms that applied for a loan, except that this analysis considers all firms seeking credit and treats those who did not apply for fear of rejection as denials. The sample excludes firms that did not need additional credit in the preceding three years. The results, reported in Table 9, are consistent with the previous analysis; we find that selection is not much of an issue for black-owned firms. Regardless of whether we consider denial rates among applicants or denial rates among firms that desired additional credit, black-owned firms are roughly 25 percent less likely to obtain credit. For Hispanic-owned firms, however, selection bias is evident.

18 The only variable that we felt potentially could meet these conditions in the NSSBF data is the distance between a firm and the nearest financial institution. If greater distance reduced a firm's information regarding the availability of funds, it might be related to the decision to apply for a loan. On the other hand, the creditworthiness of the firm should be independent of its location and should be unlikely to enter into the approval process. Unfortunately, we did not find a direct relationship between distance to the nearest financial institution and the probability of applying for a loan. This may be due to the fact that few firms are located more than a very short distance from the nearest financial institution. 
Among the pool of loan applicants, Hispanic-owned firms are not statistically significantly more likely to be denied than other firms with the same characteristics. The previously statistically insignificant result for Hispanics in Table 5 now becomes significant in Table 9. Among the pool of firms seeking additional credit, Hispanic-owned firms are 12 percent more likely to be denied access to credit, and this difference is statistically significant.

\section{Caveats}

The results presented indicate that black-owned firms particularly face obstacles in obtaining credit that are unrelated to their credit worthiness. Although one explanation for these findings is that these firms are discriminated against, we raise a few factors worth considering before one can draw definitive conclusions.

First, as in any regression-based study, our analysis hinges upon the proposition that all the factors that are related to loan denial rates by race have been included in our statistical model. If, for example, blacks possess some unobservable characteristic that makes them less creditworthy, then our statistical finding would overstate the extent of discrimination. Although such an omitted variable bias is always a possibility, we have included an extensive array of information on firm characteristics and it is not clear what additional information would be pertinent in examining loan decisions. In addition, we have estimated alternative specifications that address other forms of credit that firms receive and different subgroups of banks and in each case the results are consistent with our interpretation that discrimination exists in this market. Finally, we have also supplemented the regression estimates with alternative, more qualitative approaches, which all suggest the possibility of discrimination in lending. 
It is conceivable that the reason why blacks are more likely to have their loans denied is that the firms that they own are inherently less profitable than the ones owned by whites. There are two counters to this argument. First, modeling a firm's profitability normalized either by equity or employment shows no evidence of racial differences. ${ }^{19}$ Second, controlling for a firm's profitability does not change the race coefficients significantly in the loan denial equations reported earlier.

Another potential criticism is that this study has examined loan denial rates rather than loan default rates; some have claimed that the latter provides a more appropriate strategy for identifying discrimination. For example, if banks only approve loans for relatively good black firms then black firms should exhibit relatively low default rates. Such an approach has several significant shortcomings that are detailed in Browne and Tootell (1995) and Ladd (1998). For instance, one problem is that it relies on the distribution of default probabilities being similar for black and white applicants meeting the acceptance standard used for white firms. A further problem is that it assumes that the loan originators know with a high degree of precision what determines defaults, but little hard information exists on what causes default. Additionally, it would be hard to disentangle the factors associated with differences in default rates between white and black-owned firms given the fact that black-owned firms that obtain credit are charged higher interest rates, as we have shown.

In addition, many of the criticisms levied against Munnell et al. (1996) may be relevant here as well. That work has been attacked because of the fragility of the results. Yet these criticisms appear to have been effectively countered by the authors (see Browne and Tootell,

\footnotetext{
${ }^{19}$ Results not reported. This is true with or without controls for industry, location, creditworthiness and all of the other controls used in the various denial equations. There is some evidence of a negative race effect in an equation where profits are normalized by sales but this is an inappropriate and certainly unusual normalization.
} 
1995; Tootell, 1996). It is also not obvious that the criticisms directed towards that research are applicable to the results presented here. Importantly, our reported estimates appear to be highly stable to changes in econometric specification. Moreover, the absolute size of the raw racial differences found in the mortgage study are considerably smaller than those observed in this study regarding business credit. ${ }^{20}$ Some of the difference in denial rates between the races in both studies appears to be due to differences in the characteristics of the applicants. Even after controlling for these differences, however, the gap in denial rates in the small business credit market is considerably larger than that found in the mortgage market. ${ }^{21}$ The larger size and significance of the effects found in this report reduce the possibility that the observed differences can be explained away by some quirk of the econometric estimation procedure.

\section{Conclusions}

Our analysis finds significant evidence that black-owned businesses face impediments to obtaining credit that go beyond observable differences in their credit worthiness. These firms are more likely to report that credit availability was a problem in the past and expect it to be a problem in the future. In fact, these concerns prevent more black-owned firms from applying for loans because they feared being turned down due to prejudice or discrimination. We also found that loan denial rates are significantly higher for black-owned firms than for white-owned firms even after taking into account differences in an extensive array of measures of credit-worthiness and other characteristics. This result appears to be largely insensitive to changes in econometric

20 In the Boston Fed study $10 \%$ of white's mortgage applications were rejected compared with $28 \%$ for blacks; loan denial rates for business credit in this study were 26.9 percent and 65.9 percent for white- and black-owned firms respectively.

21 The ceteris paribus gap between blacks and whites is 25 percentage points in denial rates between the races in 
specification. Overall, the evidence is consistent that black-owned firms are disadvantaged in the market for small business credit, which would traditionally be attributed to discrimination. We found little or no evidence that female-owned firms are discriminated against in this market.

The magnitude of the racial difference in small business loan approval rates is substantial, even after controlling for observed differences in credit-worthiness, and considerably larger than that found in the analysis of discrimination in mortgage markets. Why do the results for small business loans differ so markedly from those obtained from mortgage loans? First, many mortgages are sold in the secondary market and a substantial fraction of mortgage lenders have little intention of keeping the loans they make. This added "distance" in the transaction might reduce the likelihood of discrimination. As Day and Liebowitz, (1998) point out, "economic selfinterest, therefore, should reduce racial discrimination in this market more completely than in many others" (p.6). A highly sophisticated secondary market for loans to small firms does not exist. Second, the presence of special programs and regulatory incentives to encourage banks and others to increase their mortgage lending to minorities gives these groups some advantages in obtaining a mortgage. Additional research might seek to provide alternative explanations.

the small business credit market compared with 7 percentage points in the mortgage market. 


\section{$\underline{\text { References }}$}

Bates, T., (1989). "The Changing Nature of Minority Business: A Comparative Analysis of Asian, Non-minority, and Black-Owned Businesses," The Review of Black Political Economy, pp. $25-42$.

Bauer, P.W. and B.A. Cromwell (1994). "A Monte Carlo examination of bias tests in mortgage lending", Federal Reserve Bank of Cleveland Economic Review, 30(3), pp. 27-40.

Becker, G. S. (1957). The Economics of Discrimination. Chicago: University of Chicago Press.

Black, J., D. de Meza, and D. Jeffreys (1996). "House Price, the Supply of Collateral and the Enterprise Economy. Economic Journal, January, 106(434), pp. 60-75.

Blanchflower, D.G., Evans, D.S. and A.J. Oswald (1998a). "Credit cards and entrepreneurs", working paper, National Economic Research Associates, Cambridge, MA.

Blanchflower, D.G., Evans, D.S. and A.J. Oswald (1998b). "Credit cards and consumers", working paper, National Economic Research Associates, Cambridge, MA.

Blanchflower, D.G. and A.J. Oswald. "What makes an entrepreneur?", Journal of Labor Economics, January, 16(1), pp. 26-60 1998.

Browne, L. E. and G. M.B. Tootell, (1995). "Mortgage Lending in Boston-A Response to the Critics", New England Economic Review, pp. 53-78, September-October.

Cavalluzzo, K.S. and L.C. Cavalluzzo, (1998). "Market Structure and Discrimination: The Case of Small Businesses." Journal of Money, Credit, and Banking. November, 30(4), pp. 771-792.

Cloud C. and G. Galster, (1993). "What Do We Know about Racial Discrimination in Mortgage Markets", Review of Black Political Economy, Summer, 22(1), pp. 101-120.

Cole, R.A. and J. D. Wolken, (1995). "Financial Services Used by Small Businesses: Evidence from the 1993 National Survey of Small Business Finances", Federal Reserve Bulletin, vol. 81, July, pp. 630-67.

Cole, R.A., R. L. Woodburn, and J. D. Wolken, (1996). "Bank and Nonbank Competition for Small Business Credit: Evidence from the 1987 and 1993 National Surveys of Small Business Finances", Federal Reserve Bulletin, vol. 82, November, pp. 938-95.

Day, T.S. and S.J. Liebowitz (1998). "Mortgage lending to minorities: where's the bias?" Economic Inquiry, XXXVI, January, pp. 3-28.

Evans, D. and Leighton, Linda (1989). "Some empirical aspects of entrepreneurship", American Economic Review, 79, pp. 519-535. 
Evans, D. and B. Jovanovic, (1989). "An estimated model of entrepreneurial choice under liquidity constraints", Journal of Political Economy, 97, pp. 808-827.

Fairlie, R.W. (1998). "The absence of the African-American owned business: an analysis of the dynamics of self-employment", Journal of Labor Economics, forthcoming.

Fairlie, R. W., and B. D. Meyer (1996). "Ethnic and Racial Self-Employment Differences and Possible Explanations," Journal of Human Resources, 31(4), pp. 757-793.

Ferri, G. and P. Simon (1997). "Constrained consumer lending: exploring business cycle patterns using the Survey of Consumer Finances", working paper, Princeton University.

Harrison, G.W. (1998). "Mortgage lending in Boston: a reconsideration of the evidence", Economic Inquiry, XXXVI, January, pp. 29-38.

Hayashi, F. (1985). "The effect of liquidity constraints on consumption: a cross-sectional analysis", Quarterly Journal of Economics, February, 100(1), pp. 183-206.

Heckman, J.J. (1998). "Detecting discrimination", Journal of Economic Perspectives, Spring, 12(2), pp. 101-116.

Holtz-Eakin, D., Joulfaian, D., and R.S., Harvey (1994a). "Entrepreneurial decisions and liquidity constraints", Journal of Political Economy, 102, pp. 53-75.

Holtz-Eakin, D., Joulfaian, D., and R.S., Harvey (1994b). "Sticking it out: entrepreneurial survival and liquidity constraints", Rand Journal of Economics, 25(2), pp. 334-347, Summer.

Horne, D. (1994). "Evaluating the role of race in mortgage lending", FDIC Banking Review, 7(1), Spring/Summer, pp. 1-15.

Jappelli, T. (1990). "Who is credit constrained in the U.S. economy?", Quarterly Journal of Economics, February, 105(1), pp. 219-234.

Ladd, H.F. (1998). "Evidence on discrimination in mortgage lending", Journal of Economic Perspectives, Spring, 12(2), pp. 41-62.

Lindh T., and H.Ohlsson (1996). "Self-employment and windfall gains: Evidence from the Swedish lottery", Economic Journal, November, 106: (439), pp. 1515-1526.

Munnell, A.G., M.B Tootell, L.E. Browne and J. McEneaney (1996). "Mortgage lending in Boston: interpreting HMDA data", American Economic Review, March, 86(1), pp. 25-53.

Oaxaca, R.L. (1973) "Male-Female Wage Differences in Urban Labor Markets. International Economic Review. October, 14(3), pp. 693-709. 
Tootell, G.M.B. (1996). "Turning a critical eye on the critics", in Mortgage lending, racial discrimination and federal policy, edited by J. Goering and R. Wienk, Urban Institute Press, Washington, D.C..

Yezer, M.J., R.F. Phillips and R.P. Trost (1994). "Bias in estimates of discrimination and default in mortgage lending; the effects of simultaneity and self-selection", Journal of Real Estate Finance and Economics, 9(3), pp. 196-215. 
Table 1: Selected Sample Means from 1993 NSSBF Data

\begin{tabular}{|c|c|c|c|c|c|}
\hline & All & White & Black & Hispanic & Other Races \\
\hline Loan denial rates & 0.288 & 0.269 & 0.659 & 0.359 & 0.400 \\
\hline \multicolumn{6}{|c|}{ Credit History } \\
\hline Judgments against owner & 0.051 & 0.043 & 0.150 & 0.093 & 0.092 \\
\hline Firm delinquent & 0.19 & 0.185 & 0.328 & 0.249 & 0.144 \\
\hline Personally delinquent & 0.134 & 0.12 & 0.366 & 0.223 & 0.179 \\
\hline Bankrupt past $7 \mathrm{yrs}$ & 0.027 & 0.025 & 0.051 & 0.036 & 0.038 \\
\hline \multicolumn{6}{|c|}{ Other Firm Characteristics } \\
\hline Female-owned & 0.261 & 0.257 & 0.235 & 0.277 & 0.330 \\
\hline Total employment & 8.49 & 8.75 & 6.18 & 6.73 & 6.71 \\
\hline Firm age & 14.28 & 16.42 & 11.99 & 12.92 & 10.22 \\
\hline$\$ 1992$ Sales (in 1,000s) & 1,001 & 1,057 & 421 & 685 & 599 \\
\hline$\$ 1992$ Assets (in 1,000s) & 489 & 516 & 169 & 321 & 321 \\
\hline \$1992 Liabilities (in 1,000s) & 285 & 304 & 87 & 136 & 181 \\
\hline Sole Proprietorship & 0.432 & 0.417 & 0.621 & 0.571 & 0.476 \\
\hline Partnership & 0.083 & 0.081 & 0.042 & 0.081 & 0.078 \\
\hline S Corporation & 0.203 & 0.213 & 0.097 & 0.091 & 0.185 \\
\hline C Corporation & 0.284 & 0.289 & 0.241 & 0.256 & 0.260 \\
\hline Line of credit & 0.257 & 0.264 & 0.213 & 0.275 & 0.149 \\
\hline Owner years experience & 18.9 & 19.4 & 15.8 & 15.4 & 14.7 \\
\hline$<=8$ th grade education & 0.018 & 0.015 & 0.01 & 0.075 & 0.035 \\
\hline 9-11th grade education & 0.028 & 0.028 & 0.026 & 0.033 & 0.033 \\
\hline High school graduate & 0.234 & 0.238 & 0.155 & 0.301 & 0.166 \\
\hline Some college & 0.253 & 0.254 & 0.356 & 0.208 & 0.214 \\
\hline College graduate & 0.263 & 0.261 & 0.254 & 0.269 & 0.306 \\
\hline Postgraduate education & 0.203 & 0.205 & 0.203 & 0.114 & 0.245 \\
\hline East North Central Region & 0.159 & 0.168 & 0.156 & 0.084 & 0.056 \\
\hline East South Central Region & 0.045 & 0.045 & 0.115 & 0.028 & 0.013 \\
\hline Middle Atlantic Region & 0.153 & 0.159 & 0.111 & 0.099 & 0.132 \\
\hline Mountain Region & 0.058 & 0.060 & 0.020 & 0.032 & 0.052 \\
\hline New England & 0.069 & 0.074 & 0.025 & 0.026 & 0.050 \\
\hline Pacific Region & 0.182 & 0.164 & 0.181 & 0.413 & 0.307 \\
\hline South Atlantic Region & 0.148 & 0.148 & 0.229 & 0.127 & 0.118 \\
\hline West North Central Region & 0.081 & 0.088 & 0.051 & 0.020 & 0.023 \\
\hline West South Central Region & 0.100 & 0.090 & 0.108 & 0.164 & 0.245 \\
\hline Sample Size (unweighted) & 4637 & 3559 & 442 & 290 & 344 \\
\hline
\end{tabular}

Notes: Sample weights are used to provide statistics that are nationally representative of all small businesses. Some variable means are computed from slightly smaller samples because of missing values.

Source: Authors' calculations from 1993 NSSBF. 
Table 2: Problems Firms Experienced During Preceding 12 Months

\begin{tabular}{lrrrrr}
\hline \hline & & & & & \\
& All & White & Black & Hispanic & Other \\
\hline Credit Market Conditions & & & & & \\
\% reporting not a problem & 66 & 67 & 43 & 59 & 66 \\
\% reporting somewhat of a problem & 20 & 20 & 26 & 18 & 21 \\
\% reporting serious problem & 14 & 13 & 31 & 23 & 13 \\
& & & & & \\
& & & & & \\
Other Potential Problems & & & & & \\
(\% reporting problem is serious) & & & & & \\
& & & & & \\
Training costs & 7 & 7 & 7 & 30 & 29 \\
Worker's compensation costs & 22 & 21 & 19 & 45 & 35 \\
Health insurance costs & 33 & 32 & 38 & 17 & 14 \\
IRS regulation or penalties & 12 & 12 & 17 & 7 & 11 \\
Environmental regulations & 8 & 8 & 6 & 3 & 4 \\
Americans with Disabilities Act & 3 & 3 & 4 & 4 & 6 \\
Occupational Safety and Health Act & 5 & 5 & 4 & 3 & 5 \\
Family and Medical Leave Act & 3 & 3 & 5 & 3 \\
\hline \hline
\end{tabular}

Source: Authors' calculations from 1993 NSSBF 
Table 3A: Reported Factors Affecting Business Profitability

\begin{tabular}{|c|c|c|c|c|c|c|}
\hline \multirow[b]{2}{*}{ Factors } & \multicolumn{3}{|c|}{ White } & \multicolumn{3}{|c|}{ Other } \\
\hline & All & Men & Black & Hispanic & Races & Women \\
\hline \multicolumn{7}{|l|}{ 1) Lack of Financial Capital } \\
\hline$\%$ reporting minor negative impact & 25.2 & 25.6 & 19.5 & 22.1 & 20.0 & 25.5 \\
\hline$\%$ reporting strong negative impact & 30.7 & 29.0 & 46.4 & 38.1 & 33.3 & 32.9 \\
\hline \multicolumn{7}{|l|}{ 2) Health Insurance Costs } \\
\hline$\%$ reporting minor negative impact & 22.2 & 22.9 & 14.0 & 17.2 & 20.5 & 21.4 \\
\hline$\%$ reporting strong negative impact & 25.0 & 25.4 & 22.6 & 24.4 & 16.9 & 24.9 \\
\hline \multicolumn{7}{|l|}{ 3) IRS Regulations or Penalties } \\
\hline$\%$ reporting minor negative impact & 23.2 & 24.2 & 17.3 & 21.8 & 20.8 & 21.8 \\
\hline$\%$ reporting strong negative impact & 19.6 & 21.0 & 21.0 & 20.3 & 14.5 & 16.1 \\
\hline \multicolumn{7}{|l|}{ 4) Environmental Regulations } \\
\hline$\%$ reporting minor negative impact & 20.4 & 21.6 & 15.2 & 20.1 & 18.6 & 16.5 \\
\hline$\%$ reporting strong negative impact & 12.3 & 13.2 & 8.1 & 11.7 & 13.8 & 10.2 \\
\hline \multicolumn{7}{|l|}{ 5) The Americans with Disabilities Act } \\
\hline$\%$ reporting minor negative impact & 9.6 & 9.7 & 7.7 & 10.1 & 11.2 & 9.0 \\
\hline$\%$ reporting strong negative impact & 4.4 & 4.5 & 3.6 & 3.5 & 7.6 & 3.7 \\
\hline \multicolumn{7}{|l|}{$\begin{array}{l}\text { 6) The Occupational Safety and Health } \\
\text { Act }\end{array}$} \\
\hline$\%$ reporting minor negative impact & 17.3 & 18.7 & 13.9 & 14.3 & 17.1 & 13.1 \\
\hline$\%$ reporting strong negative impact & 9.0 & 9.5 & 6.3 & 9.7 & 7.6 & 8.1 \\
\hline \multicolumn{7}{|l|}{ 7) Credit Market Conditions } \\
\hline$\%$ reporting minor negative impact & 16.2 & 16.2 & 15.0 & 16.0 & 16.4 & 15.9 \\
\hline$\%$ reporting strong negative impact & 15.0 & 13.4 & 19.6 & 16.7 & 15.0 & 17.8 \\
\hline \multicolumn{7}{|l|}{ 8) Crime } \\
\hline$\%$ reporting minor negative impact & 26.5 & 26.6 & 29.4 & 27.6 & 29.8 & 25.8 \\
\hline$\%$ reporting strong negative impact & 9.2 & 7.9 & 20.6 & 16.5 & 19.9 & 9.3 \\
\hline
\end{tabular}

Table 3B: Reported Factors Contributing to Failure among Discontinued Businesses from the 1992 Characteristics of Business Owners Survey

\begin{tabular}{lrrrrrr}
\hline \hline & & White & & \multicolumn{3}{c}{ Other } \\
Factors (\% reporting) & All & Men & Black & Hispanic & Races & Women \\
\hline Lack of Access to Business Credit & 8.2 & 7.3 & 15.5 & 8.8 & 6.1 & 9.3 \\
Lack of Access to Personal Credit & 3.3 & 2.7 & 8.4 & 5.8 & 6.4 & 3.3 \\
Inadequate Cash Flow & 71.7 & 73.7 & 63.4 & 67.1 & 67.6 & 70.2 \\
Other & 71.7 & 69.3 & 69.3 & 68.3 & 75.9 & 75.8 \\
\hline \hline
\end{tabular}

Notes: The source for Tables 3A and 3B is, Characteristics of Business Owners Survey: 1992. Table 1, p. 21. 
Table 4: Percentage of Firms Reporting Most Important Issues Affecting Them Over the Next 12 Months

\begin{tabular}{lrrrrr}
\hline \hline & All & White & Black & Hispanic & Other \\
\hline Credit availability & 6 & 6 & 21 & 5 & 4 \\
& & & & & \\
Health care, health insurance & 21 & 22 & 12 & 14 & 15 \\
Taxes, tax policy & 6 & 6 & 3 & 8 & 4 \\
General U.S. business conditions & 12 & 11 & 9 & 14 & 17 \\
High interest rates & 5 & 6 & 2 & 3 & 4 \\
Costs of conducting business & 3 & 3 & 4 & 4 & 4 \\
Labor force problems & 3 & 3 & 4 & 6 & 4 \\
Profits, cash flow, expansion, sales & 10 & 10 & 20 & 10 & 12 \\
& & & & & \\
Number of observations (unweighted) & 4,388 & 3,383 & 424 & & \\
\end{tabular}

Source: Authors' calculations from 1993 NSSBF. 
Table 5: Determinants of Loan Denial Rates

(Reported Estimates are Derivatives from Probit Models, t-Statistics are in Parentheses)

\begin{tabular}{|c|c|c|c|c|}
\hline & $(1)$ & $(2)$ & $(3)$ & $(4)$ \\
\hline Black & $\begin{array}{c}0.426 \\
(10.87)\end{array}$ & $\begin{array}{l}0.277 \\
(6.69)\end{array}$ & $\begin{array}{l}0.249 \\
(5.99)\end{array}$ & $\begin{array}{l}0.258 \\
(5.85)\end{array}$ \\
\hline Asian/Pacific Islanders & $\begin{array}{l}0.207 \\
(3.90)\end{array}$ & $\begin{array}{l}0.161 \\
(3.02)\end{array}$ & $\begin{array}{l}0.128 \\
(2.42)\end{array}$ & $\begin{array}{l}0.104 \\
(1.92)\end{array}$ \\
\hline American Indian/Alaskan Eskimo & $\begin{array}{c}-0.051 \\
(0.35)\end{array}$ & $\begin{array}{c}-0.152 \\
(1.17)\end{array}$ & $\begin{array}{c}-0.143 \\
(1.07)\end{array}$ & $\begin{array}{l}-0.101 \\
(0.70)\end{array}$ \\
\hline Hispanic & $\begin{array}{l}0.113 \\
(2.33)\end{array}$ & $\begin{array}{l}0.061 \\
(1.27)\end{array}$ & $\begin{array}{l}0.055 \\
(1.15)\end{array}$ & $\begin{array}{l}0.034 \\
(0.69)\end{array}$ \\
\hline Female-Owned & $\begin{array}{l}0.073 \\
(2.54)\end{array}$ & $\begin{array}{l}0.039 \\
(1.36)\end{array}$ & $\begin{array}{l}0.029 \\
(1.00)\end{array}$ & $\begin{array}{l}0.018 \\
(0.62)\end{array}$ \\
\hline Owner years experience & & $\begin{array}{c}-0.003 \\
(2.58)\end{array}$ & $\begin{array}{l}-0.001 \\
(1.14)\end{array}$ & $\begin{array}{c}-0.002 \\
(1.51)\end{array}$ \\
\hline Owners' share of business & & $\begin{array}{l}0.001 \\
(1.96)\end{array}$ & $\begin{array}{l}0.000 \\
(0.73)\end{array}$ & $\begin{array}{c}0.00 \\
(0.12)\end{array}$ \\
\hline Judgments & & $\begin{array}{l}0.142 \\
(2.83)\end{array}$ & $\begin{array}{l}0.131 \\
(2.61)\end{array}$ & $\begin{array}{l}0.129 \\
(2.50)\end{array}$ \\
\hline Firm delinquent & & $\begin{array}{l}0.177 \\
(6.54)\end{array}$ & $\begin{array}{l}0.182 \\
(6.63)\end{array}$ & $\begin{array}{l}0.201 \\
(7.04)\end{array}$ \\
\hline Personally delinquent & & $\begin{array}{l}0.160 \\
(4.41)\end{array}$ & $\begin{array}{l}0.145 \\
(3.97)\end{array}$ & $\begin{array}{l}0.143 \\
(3.86)\end{array}$ \\
\hline Bankrupt past $7 \mathrm{yrs}$ & & $\begin{array}{l}0.208 \\
(3.10)\end{array}$ & $\begin{array}{l}0.169 \\
(2.57)\end{array}$ & $\begin{array}{l}0.154 \\
(2.30)\end{array}$ \\
\hline$\$ 1992$ Sales* $\left(10^{8}\right)$ & & $\begin{array}{l}-0.439 \\
(3.62)\end{array}$ & $\begin{array}{l}-0.332 \\
(2.52)\end{array}$ & $\begin{array}{l}-0.382 \\
(2.63)\end{array}$ \\
\hline$\$ 1992$ Assets $\left(* 10^{8}\right)$ & & $\begin{array}{c}-0.168 \\
(0.65)\end{array}$ & $\begin{array}{l}0.109 \\
(0.42)\end{array}$ & $\begin{array}{l}0.195 \\
(0.69)\end{array}$ \\
\hline$\$ 1992$ liabilities $\left(* 10^{8}\right)$ & & $\begin{array}{l}0.716 \\
(1.80)\end{array}$ & $\begin{array}{l}0.217 \\
(0.54)\end{array}$ & $\begin{array}{l}0.139 \\
(0.33)\end{array}$ \\
\hline Line of credit & & & $\begin{array}{c}-0.109 \\
(4.90)\end{array}$ & $\begin{array}{c}-0.104 \\
(4.50)\end{array}$ \\
\hline Total employment & & & $\begin{array}{c}0.0002 \\
(1.14)\end{array}$ & $\begin{array}{c}0.0002 \\
(1.05)\end{array}$ \\
\hline
\end{tabular}


Firm age

$\begin{array}{ll}-0.001 & -0.000 \\ (1.11) & (0.38)\end{array}$

(1.11) (0.38)

In an MSA

$0.094 \quad 0.087$

(3.71) (3.25)

New firm since 1990

$0.108 \quad 0.128$

(2.56)

(2.93)

Partnership

$-0.077 \quad-0.085$

(1.64)

(1.81)

S-Corporation

$-0.018 \quad-0.028$

(0.54) (0.84)

C-Corporation

$-0.041 \quad-0.048$

(1.26) (1.44)

Owner education dummies

$5 \quad 5$

Area dummies

8

Industry dummies

60

\begin{tabular}{lcccc}
$\mathrm{N}$ & 2,007 & 2,007 & 2,007 & 1,986 \\
Pseudo $\mathrm{R}^{2}$ & 0.061 & 0.141 & 0.163 & 0.194 \\
$\mathrm{Chi}^{2}$ & 143.0 & 332.5 & 385.8 & 454.7 \\
Log likelihood & $-1,109.0$ & $-1,014.3$ & -987.6 & -945.4 \\
\hline \hline
\end{tabular}

Source: Authors' calculations from 1993 NSSBF. 
Table 6: Alternative Models of Loan Denials

(Probit Derivatives, $\mathrm{t}$-statistics in Parentheses)

\begin{tabular}{|c|c|c|c|c|c|}
\hline Specification & Black & $\begin{array}{l}\text { Asian/Pacific } \\
\text { Islanders } \\
\end{array}$ & $\begin{array}{c}\text { Native } \\
\text { Americans } \\
\end{array}$ & Hispanic & Sample Size \\
\hline \multicolumn{6}{|l|}{ Creditworthiness } \\
\hline 1) No past problems & $\begin{array}{l}.236 \\
(4.12)\end{array}$ & $\begin{array}{l}.150 \\
(2.62)\end{array}$ & - & $\begin{array}{l}-.007 \\
(0.16)\end{array}$ & 1329 \\
\hline 2) One or more problem & $\begin{array}{c}.283 \\
(4.15)\end{array}$ & $\begin{array}{c}.020 \\
(0.18)\end{array}$ & $\begin{array}{c}-.115 \\
(0.47)\end{array}$ & $\begin{array}{l}.217 \\
(2.06)\end{array}$ & 591 \\
\hline 3) More than one problem & $\begin{array}{l}.252 \\
(2.28)\end{array}$ & $\begin{array}{l}.134 \\
(0.68)\end{array}$ & $\begin{array}{l}-.319 \\
(0.83)\end{array}$ & $\begin{array}{l}.074 \\
(0.39)\end{array}$ & 200 \\
\hline \multicolumn{6}{|l|}{ Source of Loan } \\
\hline 4) Suppliers: Trade Credit & $\begin{array}{l}0.032 \\
(2.88)\end{array}$ & $\begin{array}{l}0.010 \\
(0.73)\end{array}$ & $\begin{array}{l}-0.032 \\
(1.06)\end{array}$ & $\begin{array}{l}0.029 \\
(2.08)\end{array}$ & 4,480 \\
\hline 5) Credit Card: Business & $\begin{array}{l}0.035 \\
(1.33)\end{array}$ & $\begin{array}{l}-0.102 \\
(3.42)\end{array}$ & $\begin{array}{l}0.050 \\
(0.60)\end{array}$ & $\begin{array}{l}0.032 \\
(1.02)\end{array}$ & 4,628 \\
\hline 6) Credit Card: Personal & $\begin{array}{l}0.002 \\
(0.07)\end{array}$ & $\begin{array}{l}-0.009 \\
(0.07)\end{array}$ & $\begin{array}{l}-0.008 \\
(0.09)\end{array}$ & $\begin{array}{l}-0.036 \\
(1.17)\end{array}$ & 4,635 \\
\hline \multicolumn{6}{|l|}{ Organization Type } \\
\hline $\begin{array}{l}\text { 7) Proprietorships and } \\
\text { Partnerships }\end{array}$ & $\begin{array}{l}0.240 \\
(2.87)\end{array}$ & $\begin{array}{c}.074 \\
(0.71)\end{array}$ & $\begin{array}{l}.670 \\
(1.86)\end{array}$ & $\begin{array}{l}.058 \\
(0.66)\end{array}$ & 522 \\
\hline 8) Corporations & $\begin{array}{l}0.243 \\
(4.46)\end{array}$ & $\begin{array}{l}.123 \\
(1.83)\end{array}$ & --- & $\begin{array}{l}.025 \\
(0.40)\end{array}$ & 1,438 \\
\hline \multicolumn{6}{|l|}{ Age of Firm } \\
\hline 9) 12 Years or Under & $\begin{array}{l}0.310 \\
(5.15)\end{array}$ & $\begin{array}{l}0.169 \\
(2.32)\end{array}$ & $\begin{array}{l}-0.059 \\
(0.31)\end{array}$ & $\begin{array}{l}0.043 \\
(0.61)\end{array}$ & 1,062 \\
\hline 10) Over 12 Years & $\begin{array}{l}0.218 \\
(3.16)\end{array}$ & $\begin{array}{l}0.021 \\
(0.23)\end{array}$ & --- & $\begin{array}{c}0.65 \\
(0.94)\end{array}$ & 883 \\
\hline \multicolumn{6}{|l|}{1990 Firm Size } \\
\hline $\begin{array}{l}\text { 11) Fewer than } 10 \\
\text { Employees }\end{array}$ & $\begin{array}{l}0.258 \\
(4.45)\end{array}$ & $\begin{array}{c}.064 \\
(0.83)\end{array}$ & $\begin{array}{l}-.030 \\
(0.15)\end{array}$ & $\begin{array}{l}.016 \\
(0.24)\end{array}$ & 947 \\
\hline 12) 10 or More Employees & $\begin{array}{l}0.293 \\
(3.62)\end{array}$ & $\begin{array}{l}.145 \\
(1.66)\end{array}$ & - & $\begin{array}{l}.072 \\
(0.88)\end{array}$ & 1,004 \\
\hline \multicolumn{6}{|l|}{ Industry } \\
\hline $\begin{array}{l}\text { 13) Retail Trade, Repair } \\
\text { and Personal Services }\end{array}$ & $\begin{array}{l}0.008 \\
(0.10)\end{array}$ & $\begin{array}{l}.259 \\
(2.33)\end{array}$ & --- & $\begin{array}{l}.053 \\
(0.63)\end{array}$ & 542 \\
\hline 14) All Other Industries & $\begin{array}{l}0.329 \\
(6.40)\end{array}$ & $\begin{array}{l}.083 \\
(1.27)\end{array}$ & $\begin{array}{l}-.107 \\
(0.73)\end{array}$ & $\begin{array}{l}.095 \\
(1.50)\end{array}$ & 1,443 \\
\hline \multicolumn{6}{|l|}{ Urban/rural } \\
\hline 15) MSA & $\begin{array}{l}.241 \\
(5.08)\end{array}$ & $\begin{array}{l}.100 \\
(1.71)\end{array}$ & $\begin{array}{l}-.203 \\
(1.27)\end{array}$ & $\begin{array}{l}-.034 \\
(0.64)\end{array}$ & 1558 \\
\hline 16) Non-MSA & $\begin{array}{r}.485 \\
(2.99) \\
\end{array}$ & $\begin{array}{l}-.047 \\
(0.51) \\
\end{array}$ & $\begin{array}{l}.261 \\
(1.03) \\
\end{array}$ & $\begin{array}{c}.403 \\
(3.00) \\
\end{array}$ & 387 \\
\hline
\end{tabular}

Notes: Each line of this table represents a separate regression with the same control variables as Column 4 of Table 5. The dependent variable in all specifications except those for credit cards represents an indicator for whether or not a loan application was denied. For credit cards, the dependent variable indicates whether the firm used business or personal credit cards to finance business expenses. In the source of loan specifications, the sample size is all firms. In models separated by industry, firm size, and firm age, the sample size reflects the number of loan applications in each category. Native Americans include American Indians and Alaskan Eskimo.

Source: Authors' calculations from 1993 NSSBF. 
Table 7: Models of Interest Rate Charged

(OLS coefficients, t-statistics in Parentheses)

\begin{tabular}{|c|c|c|c|c|c|c|}
\hline Specification & Black & $\begin{array}{l}\text { Asian/Pacific } \\
\text { Islanders }\end{array}$ & $\begin{array}{c}\text { Native } \\
\text { Americans }\end{array}$ & Hispanic & $\begin{array}{l}\text { Fixed Interest } \\
\text { Loan }\end{array}$ & $\begin{array}{l}\text { Sample } \\
\text { Size }\end{array}$ \\
\hline 1) All Loans & $\begin{array}{l}1.029 \\
(3.72)\end{array}$ & $\begin{array}{c}.450 \\
(1.47)\end{array}$ & $\begin{array}{l}-.480 \\
(0.68)\end{array}$ & $\begin{array}{l}.471 \\
(1.78)\end{array}$ & $\begin{array}{c}.496 \\
(4.22)\end{array}$ & 1455 \\
\hline 2) No credit problems & $\begin{array}{l}1.494 \\
(4.24)\end{array}$ & $\begin{array}{l}.381 \\
(1.08)\end{array}$ & $\begin{array}{l}.981 \\
(1.15)\end{array}$ & $\begin{array}{c}.414 \\
(1.46)\end{array}$ & $\begin{array}{c}.511 \\
(3.98)\end{array}$ & 1138 \\
\hline \multicolumn{7}{|l|}{ Organization Type } \\
\hline $\begin{array}{l}\text { 3) Proprietorships and } \\
\text { Partnerships }\end{array}$ & $\begin{array}{l}1.679 \\
(2.77)\end{array}$ & $\begin{array}{l}.671 \\
(0.97)\end{array}$ & $\begin{array}{l}1.498 \\
(0.55)\end{array}$ & $\begin{array}{l}.387 \\
(0.70)\end{array}$ & $\begin{array}{l}.608 \\
(2.11)\end{array}$ & 365 \\
\hline 4) Corporations & $\begin{array}{r}.721 \\
(2.32)\end{array}$ & $\begin{array}{l}.399 \\
(1.16)\end{array}$ & $\begin{array}{l}-.646 \\
(0.93)\end{array}$ & $\begin{array}{l}.635 \\
(2.04)\end{array}$ & $\begin{array}{c}.414 \\
(3.24)\end{array}$ & 1090 \\
\hline \multicolumn{7}{|l|}{ Age of Firm } \\
\hline 5) 12 years or under & $\begin{array}{l}1.336 \\
(3.38)\end{array}$ & $\begin{array}{c}.377 \\
(0.86)\end{array}$ & $\begin{array}{l}-.520 \\
(0.58)\end{array}$ & $\begin{array}{l}.386 \\
(1.01)\end{array}$ & $\begin{array}{l}.646 \\
(3.59)\end{array}$ & 721 \\
\hline 6) Older than 12 years & $\begin{array}{r}.676 \\
(1.65)\end{array}$ & $\begin{array}{l}.696 \\
(1.50)\end{array}$ & $\begin{array}{l}-.011 \\
(0.01)\end{array}$ & $\begin{array}{l}.680 \\
(1.76)\end{array}$ & $\begin{array}{l}.351 \\
(2.18)\end{array}$ & 734 \\
\hline \multicolumn{7}{|l|}{1990 Firm Size } \\
\hline $\begin{array}{l}\text { 7) Fewer than } 10 \\
\text { Employees }\end{array}$ & $\begin{array}{l}1.151 \\
(2.85)\end{array}$ & $\begin{array}{l}.302 \\
(0.62)\end{array}$ & $\begin{array}{r}-1.040 \\
(0.85)\end{array}$ & $\begin{array}{l}.590 \\
(1.49)\end{array}$ & $\begin{array}{l}.728 \\
(3.46)\end{array}$ & 644 \\
\hline $\begin{array}{l}\text { 8) } 10 \text { or More } \\
\text { Employees }\end{array}$ & $\begin{array}{l}.493 \\
(1.12)\end{array}$ & $\begin{array}{l}.628 \\
(1.52)\end{array}$ & $\begin{array}{l}-.058 \\
(0.07)\end{array}$ & $\begin{array}{l}.676 \\
(1.61)\end{array}$ & $\begin{array}{l}.399 \\
(2.86)\end{array}$ & 811 \\
\hline \multicolumn{7}{|l|}{ Industry } \\
\hline $\begin{array}{l}\text { 9) Retail Trade, Repair } \\
\text { and Personal Services }\end{array}$ & $\begin{array}{c}.653 \\
(1.06)\end{array}$ & $\begin{array}{l}-.164 \\
(0.21)\end{array}$ & $\begin{array}{l}4.157 \\
(1.72)\end{array}$ & $\begin{array}{l}.383 \\
(0.75)\end{array}$ & $\begin{array}{l}.500 \\
(1.84)\end{array}$ & 392 \\
\hline 10) All Other Industries & $\begin{array}{c}.653 \\
(1.06)\end{array}$ & $\begin{array}{c}.667 \\
(2.05)\end{array}$ & $\begin{array}{c}-.979 \\
(1.40)\end{array}$ & $\begin{array}{c}.552 \\
(1.72)\end{array}$ & $\begin{array}{c}.452 \\
(3.48)\end{array}$ & 1063 \\
\hline \multicolumn{7}{|l|}{ Urban/rural } \\
\hline 11) MSA & $\begin{array}{l}1.164 \\
(3.94)\end{array}$ & $\begin{array}{c}.533 \\
(1.62)\end{array}$ & $\begin{array}{l}-.554 \\
(0.66)\end{array}$ & $\begin{array}{c}.505 \\
(1.75)\end{array}$ & $\begin{array}{c}.458 \\
(3.25)\end{array}$ & 1103 \\
\hline 12) Non-MSA & $\begin{array}{l}-.640 \\
(0.57)\end{array}$ & $\begin{array}{l}-.419 \\
(0.39)\end{array}$ & $\begin{array}{c}.724 \\
(0.56)\end{array}$ & $\begin{array}{l}-.029 \\
(0.04)\end{array}$ & $\begin{array}{c}.477 \\
(2.16)\end{array}$ & 352 \\
\hline
\end{tabular}

Notes: Each line of this table represents a separate regression with the same control variables as Column 4 of Table 5 except for an indicator variable for whether the loan request was for a fixed interest rate loan. Sample consists of firms who had applied for a loan and had their application approved. Native Americans include American Indians and Alaskan Eskimo. 'No credit problems' means that neither the firm nor the owner had been delinquent on payments over 60 days, no judgements against the owner for the preceding 3 years and the owner had not been bankrupt in the preceding 7 years..

Source: Authors' calculations from 1993 NSSBF. 
Table 8: Racial Differences in Failing to Apply for Loans Fearing Denial

(Probit Derivatives, t-statistics in Parentheses)

\begin{tabular}{lcccc}
\hline \hline Specification & Black & $\begin{array}{c}\text { Asian/Pacific } \\
\text { Islanders }\end{array}$ & Native Americans & Hispanic \\
\hline $\begin{array}{l}\text { No Other Control Variables } \\
(\mathrm{n}=4,635)\end{array}$ & 0.398 & 0.094 & -0.135 & 0.223 \\
& $(16.57)$ & $(3.49)$ & $(1.76)$ & $(7.89)$ \\
$\begin{array}{l}\text { Full Set of Control Variables } \\
\text { (same as Table 5, Column 4) } \\
(\mathrm{n}=4,627)\end{array}$ & 0.262 & 0.041 & 0.036 & 0.149 \\
& $(10.13)$ & $(1.48)$ & $(0.50)$ & $(5.17)$ \\
\hline \hline
\end{tabular}

Notes: Sample consists of all firms. Native Americans include American Indians and Alaskan Eskimo. Dependent variable is 1 if the firm said they did not apply for a loan fearing denial, zero otherwise.

Source: Authors' calculations from 1993 NSSBF.

Table 9: Models of Failure to Obtain Credit Among Firms that Desired Additional Credit (Probit Derivatives, $\mathrm{t}$-statistics in Parentheses)

\begin{tabular}{lcccc}
\hline \hline Specification & Black & $\begin{array}{c}\text { Asian/Pacific } \\
\text { Islanders }\end{array}$ & Native Americans & Hispanic \\
\hline $\begin{array}{l}\text { No Other Control Variables } \\
(\mathrm{n}=2,647)\end{array}$ & 0.437 & 0.283 & 0.163 & 0.268 \\
& $(14.17)$ & $(6.47)$ & $(1.37)$ & $(6.93)$ \\
Full Set of Control Variables & 0.282 & 0.152 & 0.009 & 0.127 \\
$\begin{array}{l}\text { (same as Table 5, Column 4) } \\
(\mathrm{n}=2,638)\end{array}$ & $(7.22)$ & $(2.92)$ & $(0.06)$ & $(2.78)$ \\
& & & & \\
\hline \hline
\end{tabular}

Notes: The sample consists of all firms that applied for loans along with those who needed credit, but didn't apply for fear of refusal. Failure to obtain credit includes those firms that were denied and those that did not apply for fear of refusal. Dependent variable $=1$ if the firm failed to obtain credit and zero if the firm applied for credit and had their loan application approved. Native Americans include American Indians and Alaskan Eskimo.

Source: Authors' calculations from 1993 NSSBF. 


\section{Appendix A. Data Appendix}

\section{The 1993 National Survey of Small Business Finances}

The 1993 National Survey of Small Business Finances provides information about a nationally representative sample of small businesses in the United States. The survey was conducted during 1994-95 for the Board of Governors of the Federal Reserve System and the U.S. Small Business Administration. The target population is the population of all for-profit, non-financial, non-farm business enterprises that had fewer than 500 employees and were in operation as of year-end 1992. The sample was drawn from firms listed on the Dun's Market Identifier file as of November, 1993. The DMI list, containing nearly 10 million businesses, is broadly representative of all businesses but does not include many of the newest start-up firms or the self-employed individuals filing business tax returns. In contrast, the Internal Revenue Service reports that for 1991 about 20 million individuals filed business tax returns, including about 13 million sole proprietorships, of which about 3 million reported less than $\$ 2,500$ in annual receipts. The public use dataset contains 4,637 firms. These firms represent 4.99 million small businesses.

The sample was a stratified random design with over sampling to ensure the ability to estimate separately the reporting domains by employment size groups, urban or rural location, and in census regions. The specific sampling strata were five employment-size groups $(0-19,20-49,50-$ 99, 100-499, unknown), nine Census regions (East North Central, East South Central, Middle Atlantic Mountain, New England, Pacific, South Atlantic, West North Central and West South Central), and urban or rural location. In addition, three minority partitions of firms likely to be owned by Asians, Blacks, and Hispanics were extracted from the Dun's frames prior to sampling to create samples of minority-owned businesses (see [2] for details). Each of the minority partitions was proportionately stratified by urban or rural location. Because the larger and minority-owned firms are small percentages of the population of small businesses but are of special interest to researchers, the survey over sampled larger firms (20 to 499 employees), as well as Black-owned, Asian-owned, and Hispanic-owned firms to ensure sufficient numbers for analyses of these groups.

Businesses were contacted in advance of the survey to determine eligibility, verify addresses, and identify a contact person. Not all businesses were eligible (i.e., met the target-population definition). Some businesses could not be contacted, some failed at least one of the eligibility criteria (e.g., not in business, for profit, etc.), and some had erroneous frame data. The eligibility rate of sampled businesses averaged about 60 percent.

The average duration of the telephone interviews was fifty minutes. assisted telephone interviews, which were conducted by Price Waterhouse. The survey was voluntary. The response rate was about 50 percent.

The survey collected the following types of information from each business:

-Demographic information on the owners and characteristics of the firm, such as the industry to which it belongs, age, and type of organization (sections A, B, C, and D of the questionnaire). 
-An inventory of the firm's deposit and savings accounts, capital leases, credit lines, mortgages, motor vehicle loans, equipment loans, other loans, and selected other financial products. For each of these services, the supplier of the service was also identified (sections E, F, and G of the questionnaire).

-Information about the characteristics of the financial service suppliers: type (e.g., bank, individual), location vis-a-vis the firm, method of conducting business, number of years the firm has done business with the supplier, and reasons for choosing the source (sections $\mathrm{H}$ and $\mathrm{J}$ of the questionnaire and section I of the codebook).

-Experience in the past three years in applying for credit (section $\mathrm{J}$ of the questionnaire).

-Data from each firm's income statement and balance sheet (sections $\mathrm{P}, \mathrm{R}$, and $\mathrm{S}$ of the questionnaire).

-Information on the recent credit history of the firm and its owners (section $U$ of the questionnaire).

Generally, the reference period for the survey data is 1993. However, the income statement and balance sheet data were collected for fiscal year 1992 because that date was the time of the last complete set of financial statements for most firms. Sales and employment data were collected for 1992 and for 1990.

The NSSBF does not use an equal-probability sample design, so that the weights play a critical role in interpreting the survey data. The weights included with this data set are based on the original weights computed by Price Waterhouse. As is true of all surveys, there is some amount of missing data for nearly every NSSBF question. An attempt has been made to impute most missing values. The general model used to perform imputations in the NSSBF is a randomized regression model. The methodology employed is similar to that used in the first-stage procedures of the Survey of Consumer Finances. Multiple-categorical response questions (e.g., check all responses that apply) were converted to a series of yes-no responses, and then each of these yesno responses was estimated using a randomized linear-probability model (i.e., randomized regression where the dependent variable takes on one of two values). Not all variables lend themselves to estimation by regression. In particular, questions that evoked single discrete categorical responses (e.g., type of source) are typically imputed using a randomized hot-deck procedure.

Further details of the survey may be found in Cole, R.A. and J. D. Wolken, (1995) and Cole, R.A., R. L. Woodburn, and J. D. Wolken, (1996). Additional documentation, codebooks and data are available for download on the web page of the Federal Reserve Board of Governors at the following address -- http://www.bog.frb.fed.us/pubs/oss/oss3/nssbftoc.htm. 


\section{Characteristics of Business Owners Survey, 1992}

The Characteristics of Business Owners (CBO) Survey provides basic economic, demographic, and sociological data on the characteristics of minority, women, and non-minority male business owners and their business activities. The data were collected by the Bureau of the Census through a statistically chosen mail sample survey and were combined with administrative records data, which were originally obtained for use in the 1992 Economic Census. Any business which filed an IRS form 1040, Schedule C (individual proprietor-ship or self-employed person); form 1065 (partnership); or form 1120S (subchapter S corporation) in 1992 is included in the survey universe. A subchapter $\mathrm{S}$ corporation is a special IRS designation for legally incorporated businesses with 35 or fewer shareholders who, because of tax advantages, elect to be taxed as individual shareholders rather than as corporations. The 1992 CBO survey used five sampling frames: 1) Hispanic; 2) Black; 3) Other minority (Asians and Pacific Islanders, American Indians, and Alaska Natives); 4) Women; and 5) Non-minority male. Each business was eligible for sampling from exactly one $\mathrm{CBO}$ frame, to which they were assigned in the following order of precedence: Hispanic, other minority, Black, women, and non-minority male. For tabulation purposes, women-owned businesses sampled in the Hispanic, other minority, or Black frames were used to produce the estimates for women-owned businesses. The five frames were stratified by state, industry division, and receipts size class before sample selection. The total sample size was 116,557 owners, approximately evenly distributed among the five sampling frames.

Additional documentation, codebooks and results are available for download on the web page of the Bureau of the Census at the following address:- http://www.census.gov/agfs/www/cbo.html. 


\section{Appendix B: Typical Application Form Used for Small Business Loan}

1. About your Financing Request. Indicate the type and term of your loan request, as well as your plan for repayment.

What type of loan are you requesting?

\begin{tabular}{lcc} 
Fixed Rate Term Loan & Loan Requested \$: & \multicolumn{2}{c}{ Number of Months $(1-60)$} \\
Variable Rate Term Loan & Loan Requested \$: & Number of Months (1 - 60) \\
Variable Rate Line of Credit & Credit Line Requested \$: & \\
$\begin{array}{l}\text { Business Equity Loan } \\
\text { Business Equity Line of Credit }\end{array}$ & Coan Requested \$: & Number of Months (1 - 60)
\end{tabular}

What is the purpose of the loan? (Attach other pages if necessary)

What is the primary source of business income to be used for repayment of the loan requested?

\section{About the Business}

Business Name (d/b/a if any))

Street

City State Zip

Telephone

Fax

Type of Business:

Years in Business:

Number of full-time employees:

Annual revenues:\$

How long has the business been under its current ownership?

Under what legal form does the business operate?

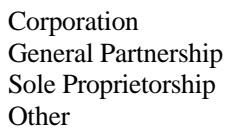

Bank Reference:

Bank Name

Account Number

Is this your primary business bank?

Yes No

3. About the Owner(s) and Guarantor(s). Provide background information about owners and guarantors.

$\begin{array}{ll}\text { Name } & \text { Name } \\ \text { Title } & \text { Title } \\ \% \text { Ownership } & \% \text { Ownership } \\ \text { Social Security Number } & \text { Social Security Number }\end{array}$

Does your business qualify as a minority-owned (more than $51 \%$ ) enterprise? Yes No

\section{Existing Assets and Liabilities of the Business}

Provide basic balance sheet information about the business

$$
\text { Original Value Current Value Loan Balance Lender/Lessor }
$$

Machinery \& Equipment

Furniture \& Fixtures

Land \& Buildings

Leasehold Improvements

Accounts Receivable

For any "yes" reply in this section, please attach a separate summary of relevant circumstances

Is the business responsible for any debts not listed on the business financial statements?

Is the business a party of any lawsuit or claim?

Does the business owe any taxes for years prior to the current year?

Is the business controlled by a person who is an executive officer of, director of, or owner

of more than $10 \%$ of any banking institution?

If yes, name of bank:

$\begin{array}{lll} & \text { Yes } & \text { No } \\ & \text { Yes } & \text { No } \\ \text { Yes } & \text { No } & \\ \text { Yes } & \text { No }\end{array}$

5. Primary Business Relationships. List the business' two largest suppliers, along with other background information about the business.

Two Largest Suppliers

$\begin{array}{llll}\text { Name } & \text { City/State } & \text { Phone } & \text { Contact Person } \\ \text { Name } & \text { City/State } & \text { Phone } & \text { Contact person }\end{array}$


Attorney

Name

\section{Accountant}

Name

Phone

Since (Date)

6. Personal Information. Provide background information about yourself and your business or employer:
Name
Residential Address
City State
Residential Telephone

Business Employers Name

Business Address

City State Zip

Business Telephone

Position or Occupation

\section{Personal Financial Condition}

\begin{tabular}{|l|l|l|l|}
\hline \multicolumn{1}{|c|}{ Assets } & In Dollars & Liabilities & In Dollars \\
\hline Cash on hand and in banks & $\$$ & Notes payable to banks & $\$$ \\
\hline Securities, marketable and closely held & $\$$ & Unpaid income tax & \\
\hline Real estate owned & & Real estate mortgages payable & \\
\hline Autos and other personal property & & Other debts & \\
\hline Cash value - life insurance & & Total Liabilities & \\
\hline Total Assets & $\$$ & Net Worth (total assets - total liabilities) & \\
\hline & & Total Liabilities plus Net Worth & \\
\hline
\end{tabular}

8. Your financial Status. List your personal income sources and bank account along with any contingent liabilities.

\section{Income}

Salary, bonuses and commissions

Dividends

Other income

Total Income

Do you have any contingent liabilities?

If yes, please describe:

As endorser, co-maker, or guarantor

On leases or contracts

Legal claims

Other special deb

Contested income tax liens

Are you a partner or officer in any other venture? If so, describe:

At what bank is your personal bank account?

$$
\text { Bank Name }
$$

\section{In Dollars}

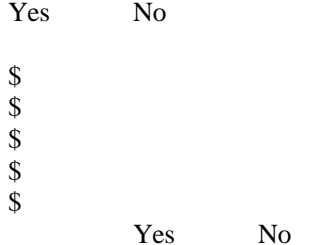

Account Number

9. Schedules. Provide detailed information about your personal assets and any personal debts.

\begin{tabular}{|l|l|l|l|l|l|}
\hline $\begin{array}{l}\text { A Securities, marketable } \\
\text { and closely held }\end{array}$ & $\begin{array}{l}\text { Number of Shares, face } \\
\text { value, or ownership share }\end{array}$ & Description & In name of & Are these pledged? & Market value \\
\hline & & & & & \\
\hline & & & & & \\
\hline
\end{tabular}

\begin{tabular}{|l|l|l|l|l|l|l|l|l|}
\hline $\begin{array}{l}\text { B Personal residence } \\
\text { \& other real estate }\end{array}$ & $\begin{array}{l}\text { Address and type } \\
\text { of property }\end{array}$ & $\begin{array}{l}\text { Title in } \\
\text { name of }\end{array}$ & $\begin{array}{l}\text { Percent of } \\
\text { ownership }\end{array}$ & $\begin{array}{l}\text { Date } \\
\text { acquire }\end{array}$ & Cost & $\begin{array}{l}\text { Market } \\
\text { value }\end{array}$ & $\begin{array}{l}\text { Mortgage } \\
\text { maturity }\end{array}$ & $\begin{array}{l}\text { Mortgage } \\
\text { amount }\end{array}$ \\
\hline & & & & & & & & \\
\hline & & & & & & & & \\
\hline
\end{tabular}

\begin{tabular}{|c|l|l|l|l|l|}
\hline C Personal installment loans & Creditor & Date issued & Secured/Unsecured & Line amount or original balance & Current balance \\
\hline & & & & & \\
\hline Credit card debt & Total Available Credit: & Total Outstanding Balance: & \\
\hline
\end{tabular}

